\title{
AUTOMATYZACJA WYBRANYCH PROCESÓW AKTUALIZACJI I KALIBRACJI MODELU SIECI WODOCIĄGOWEJ PRZY ZMIENNYCH WARUNKACH EKSPLOATACYJNYCH
}

\begin{abstract}
Modelowanie funkcjonowania systemów wodociagowych staje się coraz popularniejszym narzędziem wspomagającym zarządzanie i eksploatację nowoczesnych przedsiębiorstw wodociągowych. W znakomitej większości przypadków, powstające modele sieci odwzorowują pewien umowny stan eksploatacyjny, odpowiadający średniemu bądź maksymalnemu dobowemu zapotrzebowaniu na wodę. Istnieje wiele przeszkód natury technicznej i organizacyjnej, by można było stworzyć model odwzorowujący bieżący stan pracy systemu. W opracowaniu przedstawiono autorskie rozwiązanie poszerzające funkcjonalność symulatorów systemów wodociągowych, pozwalające na uzyskanie znacznej automatyzacji procesu dostosowania modelu do warunków bieżących, poprzez aktualizację i urealnienie wielkości zapotrzebowania na wodę oraz automatyczne dopasowanie parametrów sterujących pracą pompowni. Rozwiązanie to zostało przedstawione w formie procedury, którą można wykorzystać do implementacji w ramach dowolnego symulatora sieci wodociągowych. Procedura ta została wykorzystana do poszerzenia funkcjonalności rodzimego symulatora, bazującego na rozwiązaniach numerycznych zaczerpniętych $\mathrm{z}$ Epanet a następnie z powodzeniem przetestowana i wdrożona do eksploatacji na modelu sieci wodociągowej Nowego Sącza.
\end{abstract}

Słowa kluczowe: model sieci wodociągowej, zapotrzebowanie na wodę, Epanet, kalibracja

\section{Wstęp}

Skuteczna eksploatacja i zarządzanie strukturą tak złożoną jak system wodociągowy, niejednokrotnie wymaga wsparcia ze strony wielu narzędzi komputerowych, których funkcjonalność obejmuje między innymi gromadzenie i przetwarzanie danych o produkcji i sprzedaży wody, prowadzonych inwestycjach i wielu innych aspektach natury technicznej oraz organizacyjnej. Jedną $\mathrm{z}$ kategorii narzędzi komputerowych znajdujących zastosowanie $\mathrm{w}$ procesie

${ }^{1}$ Robert Płoskonka, Instytut Zaopatrzenia w Wodę i Ochrony Środowiska, Politechnika Krakowska, ul. Warszawska 24, 31-155 Kraków, rp@ vistula.wis.pk.edu.pl 
eksploatacji systemów wodociągowych są symulatory funkcjonowania sieci wodociągowych w zakresie hydrauliki przepływu. Typowy model sieci wodociągowej powstający $\mathrm{w}$ takim symulatorze, pomimo wielu niezaprzeczalnych zalet, posiada szereg ograniczeń funkcjonalnych, z których najistotniejsze, w kontekście niniejszego artykułu to możliwość odwzorowania jedynie pewnego umownego stanu funkcjonowania systemu, traktowanego jako miarodajny. Zazwyczaj stan ten utożsamiany jest $\mathrm{z}$ dobą o średnim bądź maksymalnym zapotrzebowaniu na wodę. Regulacje modelu dopasowane są w takiej sytuacji do jednego stanu eksploatacyjnego, przez co staje się on bardzo mało elastyczny. Postępowanie takie jest słuszne przy założeniu, że interesujące jest odwzorowanie warunków skrajnych $\left(\mathrm{np} . \mathrm{Q}_{\mathrm{dmax}}\right.$ ), które mogą stanowić podstawę do podjęcia kroków w zakresie modernizacji bądź rozbudowy istniejącej infrastruktury. Niestety, odwzorowanie o takim charakterze nie pozwala na śledzenie bieżących bądź historycznych warunków eksploatacyjnych całego systemu, choćby ze względu na ciągle zmienne zapotrzebowanie na wodę $\mathrm{i}$ w konsekwencji zmienne parametry pracy urządzeń takich jak pompy. Dostępne na rynku, znane autorowi oprogramowanie, nie pozwala na szybkie, wygodne i skuteczne dostosowanie modelu do bieżących warunków eksploatacyjnych, które w wyraźny sposób mogłyby przyczynić się do lepszego poznania i zarządzania systemem wodociągowym. W niniejszym artykule przybliżono dwa uzupełniające się rozwiązania pozwalające na skuteczne usprawnienie i automatyzację tego procesu, wraz z przykładem ich wykorzystania w bieżąco eksploatowanym modelu sieci wodociągowej. Dwa omawiane zagadnienia, związane $\mathrm{z}$ aktualizacją wielkości zapotrzebowania na wodę oraz regulacją nastaw obiektów w modelu, zostały zaimplementowane w symulatorze o nazwie Isydyw, który jest rozwiązaniem autorskim bazującym na bibliotekach numerycznych wykorzystywanych w ogólnodostępnym symulatorze Epanet 2.

\section{Model zapotrzebowania na wodę}

Na każdy model sieci wodociągowej przypada m.in. pula informacji o geometrii połączeń przewodów, ich parametrach hydraulicznych oraz sposobie funkcjonowania istotnych obiektów wodociągowych. Kluczowym uzupełnieniem tych danych są informacje o zapotrzebowaniu na wodę, które można podzielić na trzy kategorie:

- wielkość zapotrzebowania na wodę,

- zmienność poboru w czasie,

- lokalizacja poboru wody.

W przypadku modelu sieci projektowanej trudno o jednoznaczne i precyzyjne zdefiniowanie składowych dotyczących ilości i zmienności w czasie, gdyż potencjalni odbiorcy wody jeszcze z niej nie korzystają. Wartości te zakładane są z wykorzystaniem metod wskaźnikowych, a ich dokładność bywa różna. Inaczej wygląda sytuacja w przypadku odwzorowania systemu istnieją- 
cego. Tu pojawia się możliwość pomiaru rzeczywistej wielkości poboru wody wraz z dynamiką jej rozbioru w czasie oraz pomiaru przepływu w sieci. Ze względu na specyfikę prezentowanej metody, w dalszych rozważaniach skupiono się wyłącznie na próbie odwzorowania stanu bieżącego w istniejącym systemie wodociągowym.

\subsection{Lokalizacja poboru wody}

W większości symulatorów pobór wody realizowany jest poprzez wykorzystanie struktury zwanej węzłem sieci, w którym agregowane jest zapotrzebowanie z okolicznych budynków. Jest to pewna forma uproszczenia, która zauważalnie zmniejsza wymagany nakład pracy, równocześnie nie wpływając na dokładność obliczeń [1]. Lokalizacja węzła sieci jest tu równoważna przybliżonej lokalizacji odbiorcy bądź grupy odbiorców wody.

\subsection{Zmienność w czasie}

Określenie zmienności zapotrzebowania w czasie jest zagadnieniem trudnym i w przypadku braku szczegółowych pomiarów zwykle sprowadza się do identyfikacji kategorii odbiorcy i przypisania mu jednego ze standardowych rozkładów dostępnych $\mathrm{np}$. w [4]. Niestety, postępowanie takie może prowadzić do znacznych rozbieżności między wynikami obliczeń w modelu a pomiarami terenowymi i z tego względu powinno być prowadzone bardzo rozważnie. W dalszej części opracowania szerzej zostanie omówione zagadnienie szacowania zmienności zapotrzebowania w czasie symulowanego okresu jednej doby.

\subsection{Wielkość poboru wody}

Istnieje wiele metod szacowania wielkości poboru wody, niektóre z nich zostały opisane w [4] a odpowiednie regulacje prawne zawarto np. w [3]. Są to głównie metody wskaźnikowe, które nie są wolne od wad. Najistotniejszą $\mathrm{z}$ nich jest niska dokładność szacowania. W przypadku systemów istniejących, stanowczo dużo bardziej dokładne dane można pozyskać bazując na odczytach $\mathrm{z}$ indywidualnych wodomierzy. Odczyty takie prowadzone są zwykle z interwałem jednego do trzech miesięcy, tak więc uzyskana tą drogą wielkość zapotrzebowania dobowego będzie średnią, lecz mimo to dużo bardziej dokładną wartością. Taki poziom dokładności jest właściwy przy sporządzaniu modelu statycznego. Próba odwzorowania warunków bieżących wymaga jednak bardziej złożonych procedur, które pozwolą na szybką i wiarygodną aktualizację ilości pobieranej wody w obrębie całej sieci, dzielnicy bądź wydzielonej strefy. Wiąże się to jednak z koniecznością posiadania szerszego spektrum pomiarów, głównie wielkości przepływu w wybranych punktach sieci. 
Wykorzystanie trzech wyżej opisanych składowych pozwala na stworzenie kompletnego modelu zapotrzebowania na wodę, będącego integralną częścią modelu hydraulicznego. W takim modelu zapotrzebowania na wodę wiarygodne jest miejsce i średnia wielkość poboru wody. Rozkład zmienności w czasie jest przybliżony i w znacznym stopniu zależny do identyfikacji przynależności poszczególnych odbiorców do jednej z typowych grup, takich jak mieszkalnictwo czy usługi. Metoda opisana poniżej pozwala na zwiększenie wiarygodności odwzorowania tego czynnika poprzez wykorzystanie danych pomiarowych wielkości przepływu w kluczowych miejscach sieci.

\section{Metoda aktualizacji modelu zapotrzebowania na wodę}

Podstawowym założeniem prezentowanej metody aktualizacji modelu zapotrzebowania na wodę jest dostosowanie odwzorowania zmienności zapotrzebowania w czasie do danych pomiarowych poprzez modyfikację odpowiednich rozkładów godzinowych i wielkości poboru wody opisanych w modelu.

W tym celu wykorzystuje się dostępne pomiary terenowe wielkości przepływu w strategicznych miejscach sieci. Sa to dane z przepływomierzy na przewodach tłocznych ZUW i poszczególnych przepompowni, oraz dane $\mathrm{z}$ przepływomierzy umieszczonych na przewodach rozdzielających strefy bilansowania przepływu. Szczególnie te ostatnie są ważne w kontekście niniejszej metody, gdyż pozwalają na uszczegółowienie odwzorowania na mniejsze rejony sieci. Istotne jest również to, by wszystkie pomiary zostały wykonane w tym samym czasie. Na rys. 1 , jako przykład, przedstawiono podział obszaru zasi-

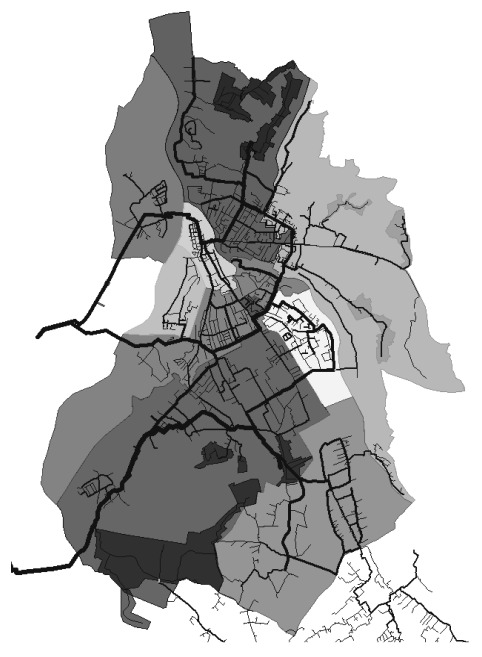

Rys. 1. Podział systemu wodociągowego na strefy bilansowania zapotrzebowania. Nowy Sącz

Fig. 1. Water supply system diversification into separete zones of water demand. Nowy Sącz lanego przez Sądeckie Wodociągi na szereg mniejszych stref bilansowania przepływów. Podział ten stanowił podstawę do opracowania modelu tego systemu wodociągowego, w którym wykorzystano prezentowaną metodę aktualizacji modelu zapotrzebowania na wodę.

\subsection{Bilansowanie zmienności w czasie i ilości wody w wydzielonej strefie}

Dysponując pomiarami przepływu na kluczowych odcinkach sieci wydzielających separowane strefy, możliwe jest ich odpowiednie sumowanie, pozwalające na zbilansowanie ilości i uzyskanie zmienności w czasie wody, która po- 
zostaje w obrębie każdej z wydzielonych stref. Jest to zarówno woda sprzedana jak i tracona np. na nieszczelnościach. Bilansowanie tego typu realizowane jest dla każdego przedziału czasowego (domyślnie jedna godzina) z wykorzystaniem wzoru:

$$
Q_{\text {strefy }}=\sum Q_{w e}-\sum Q_{w y}
$$

gdzie:

$Q_{\text {strefy }}$ - obliczona wielkość konsumpcji wody w obrębie wydzielonej strefy $\left[\mathrm{m}^{3} / \mathrm{h}\right]$,

$Q_{\text {we }}$ - przepływ przez przepływomierze, przez które woda wpływa do strefy $\left[\mathrm{m}^{3} / \mathrm{h}\right]$,

$Q_{w y} \quad$-przepływ przez przepływomierze przez które woda wypływa ze strefy $\left[\mathrm{m}^{3} / \mathrm{h}\right]$.

Na rys. 2.a - 2.c. schematycznie przedstawiono procedurę bilansowania, gdzie wynikowy rozkład (rys. 2.c) powstaje z różnicy przepływów między odczytem na wejściu (rys. 2.a) i na wyjściu ze strefy (rys. 2.b).

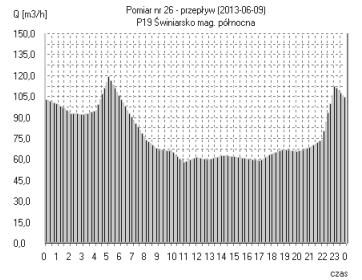

Rys. 2.a. Pomiar przepływu wody dopływającej do wydzielonej strefy

Fig. 2.a. Chart of measured amount of water entering separated zone

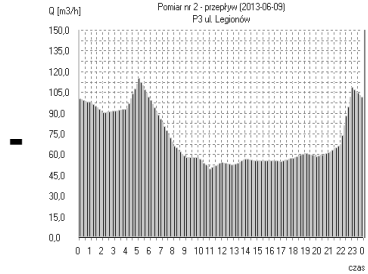

Rys. 2.b. Pomiar przepływu wody wypływającej z wydzielonej strefy

Fig. 2.b. Chart of measured amount of water leaving separated zone

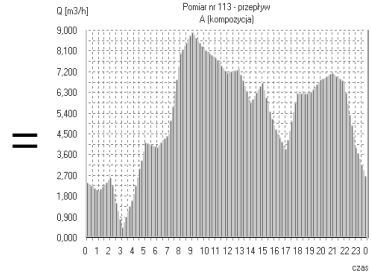

Rys. 2.c. Obraz zmienności w czasie poboru wody w wydzielonej strefie

Fig. 2.c. Chart of measured water demand in separated zone

\subsection{Szacowanie wielkości strat wody w wydzielonej strefie}

Wykorzystując obliczony wzorem (1), na bazie pomiarów terenowych, rozkład zmienności „konsumpcji” wody w wydzielonej strefie, oraz przyjmując z pewnym prawdopodobieństwem rozkład poboru wody sprzedanej, możliwe jest wyznaczenie różnicy między nimi dla każdego przedziału czasowego, korzystając z następujących relacji, które są każdorazowo wyznaczane dla kolejnych godzinowych przedziałów czasowych:

$$
Q_{\text {strat }}=Q_{\text {strefy }}-Q_{\text {sprz }}
$$




$$
\begin{aligned}
& Q_{s p r z}=\sum_{i=1}^{n} q_{s p r z}^{i} \\
& q_{s p r z}^{i}=q_{s r}^{i} \cdot u(t)
\end{aligned}
$$

gdzie:

$\mathrm{Q}_{\text {strat }}$ - obliczona wielkość strat wody w obrębie wydzielonej strefy $\left[\mathrm{m}^{3} / \mathrm{h}\right]$,

$\mathrm{Q}_{\text {strefy }}$ - obliczona wg (1) wielkość konsumpcji wody w obrębie wydzielonej strefy wodociągowej $\left[\mathrm{m}^{3} / \mathrm{h}\right]$,

$\mathrm{Q}_{\text {sprz }}$ - obliczona wg (3), sumaryczna sprzedaż wody w strefie $\left[\mathrm{m}^{3} / \mathrm{h}\right]$,

$q_{s p r z}^{i}$ - wielkość sprzedaży wody w $i$-tym punkcie pomiaru sprzedaży, w kolejnym kroku czasowym, na podstawie przyjętego rozkładu zmienności zapotrzebowania na wodę $u$, dla $i$-tego odbiorcy $\left[\mathrm{m}^{3} / \mathrm{h}\right]$,

$q_{s r}^{i}$-średnia dobowa sprzedaż wody zmierzona w $i$-tym punkcie sprzedaży wody $\left[\mathrm{m}^{3} / \mathrm{d}\right]$

$u(t)$ - wartość założonego rozkładu zmienności zapotrzebowania na wodę w kolejnym kroku czasowym [-],

$n$ - liczba węzłów sieci obciążonych zapotrzebowaniem na wodę.

Suma wartości $Q_{\text {strat }}$ dla całej doby może być utożsamiana z dobową wielkością strat na nieszczelnościach. Z perspektywy zmienności w czasie kolejnych wartości $Q_{\text {strat }}$ nie jest to już takie oczywiste ze względu na założoną $(u(t))$, a nie zmierzoną zmienność sprzedaży wody. Taka niejednoznaczność nie stanowi jednak istotnego problemu obliczeniowego, gdyż finalnie istotna jest suma obu wartości, która winna pokryć się z pomiarem na przepływomierzach. Może ona prowadzić jedynie do lokalnych rozbieżności z rzeczywistym przepływem.

Aby dopasować model zapotrzebowania do pomiarów terenowych, konieczne jest wprowadzenie korekty w zakresie ilości wody, oraz zmienności w czasie dla wszystkich węzłów sieci w obrębie wskazanej strefy bilansowania. Odbywa się to poprzez dystrybucję obliczonej ilości wody traconej pomiędzy węzły sieci, według jednego z kilku dostępnych w aplikacji scenariuszy. Zaimplementowany algorytm dystrybucji strat pozwala na przeprowadzenie jej:

- proporcjonalnie do wielkości rzeczywistego zapotrzebowania na wodę

$$
q_{\text {strat }}^{i}=Q_{\text {strat }} \cdot \frac{q_{s p r z}^{i}}{Q_{s p r z}}
$$


- proporcjonalnie do średnicy przewodu zasilającego

$$
q_{\text {strat }}^{i}=Q_{\text {strat }} \cdot \frac{D^{i}}{\sum_{i=1}^{n} D^{i}}
$$

- rozkładając straty równomiernie między obciążone węzły w strefie

$$
q_{\text {strat }}^{i}=\frac{Q_{\text {strat }}}{n}
$$

gdzie:

$\mathrm{Q}_{\text {strat }}$ - obliczona wielkość strat wody w obrębie wydzielonej strefy $\left[\mathrm{m}^{3} / \mathrm{h}\right]$,

$\mathrm{Q}_{\text {sprz }}$ - obliczona sumaryczna sprzedaż wody w obrębie strefy $\left[\mathrm{m}^{3} / \mathrm{h}\right]$,

$q_{\text {sprz }}^{i}$ - zmierzona sprzedaż wody w $i$-tym punkcie (wodomierzu) $\left[\mathrm{m}^{3} / \mathrm{h}\right]$,

$q_{\text {strat }}^{i}$ - oszacowana strata wody w okolicy $i$-tego punktu sprzedaży $\left[\mathrm{m}^{3} / \mathrm{h}\right]$,

$D^{i} \quad$ - średnica wewnętrzna przewodu doprowadzającego wodę do $i$-tego punktu sprzedaży wody [mm],

$n \quad$ - liczba węzłów sieci obciążonych zapotrzebowaniem na wodę.

Dystrybucja wyżej opisanej ilości wody związana jest z równoczesnym przypisaniem do węzła sieci odpowiedniego, obliczonego rozkładu zmienności w czasie. Należy tu zauważyć, że ta dystrybucja odbywa się według założonego algorytmu, natomiast wielkość sprzedaży wody jest już uzależniona od odczytów na indywidualnych wodomierzach. Suma tych dwóch składowych pozwala na pełne zbilansowanie ilości i zmienności w czasie wody w obrębie całej wydzielonej strefy, równocześnie utrzymując zróżnicowanie ilościowe oraz sumaryczną zmienność sprzedaży i strat w każdym węźle sieci. Procedura nie prowadzi do uśrednienia i ujednolicenia charakteru poboru wody. Pomimo sumarycznej zgodności w zakresie ilości i zmienności w czasie z odczytami terenowymi zachowany jest indywidualny charakter poboru wody w każdym węźle sieci.

\subsection{Dopasowanie wartości modelowych do danych pomiarowych}

Przedstawiony powyżej algorytm może napotkać na pewną przeszkodę wymuszającą korektę obliczeń. Wielkości sprzedaży wyliczone na bazie założonego rozkładu zmienności w czasie wg wzoru (4), w szczególnych warunkach, dla niektórych godzin mogą być większe niż wartości zmierzone. Prowadzi to do błędnych wyników sugerujących ujemne zapotrzebowanie na wodę. Zdarzenie takie może mieć miejsce przy aktualizacji modelu do warunków, w których pobór wody jest mniejszy niż $q_{s r}^{i}$ wynikające z uśrednionego odczytu 
na indywidualnych wodomierzach. W takiej sytuacji, w aplikacji rekurencyjnie realizowana jest korekta rozkładu i wielkości sprzedaży wody, tak by osiągnąć stan, w którym wielkości obliczone nie przekraczają wielkości zmierzonych w ciągu całej symulowanej doby, dla każdego węzła sieci, w każdym przedziale czasowym. Zyskiem z takiej operacji jest korekta wstępnie założonego rozkładu sprzedaży wody w kierunku rozkładu bardziej rzeczywistego, natomiast jego uzupełnienie do wielkości zmierzonej jest przybliżonym rozkładem zmienności wody traconej.

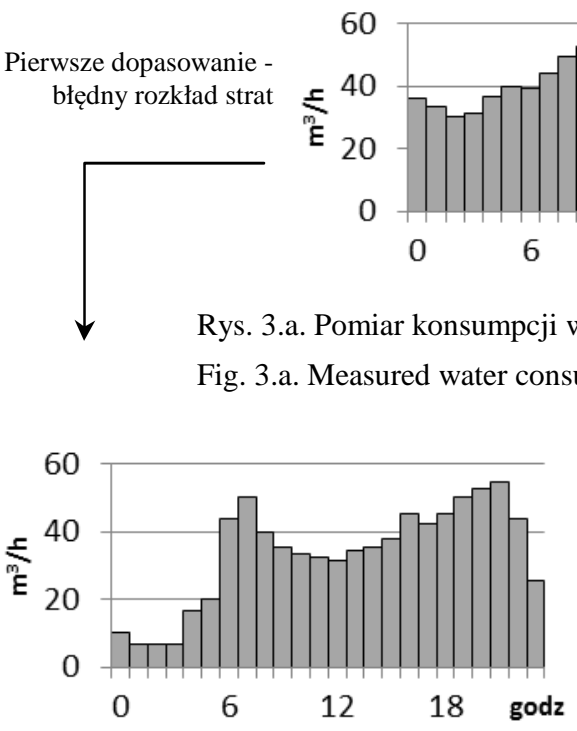

Rys. 3.b. Założony rozkład konsumpcji wody

Fig. 3.b. Assumed chart of water consumption

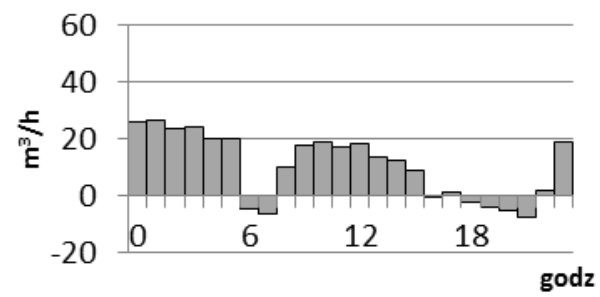

Rys. 3.c. Obliczony rozkład strat - pojawiają się wartości ujemne

Fig. 3.c. Calculated chart of water loses - negative values appeared
Kolejne dopasowanie modelu - rozkład strat bez wartości ujemnych
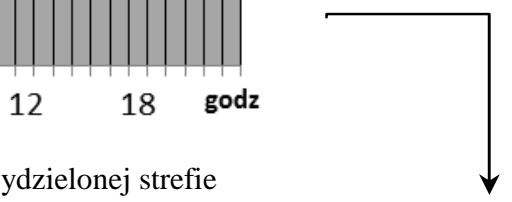

mene

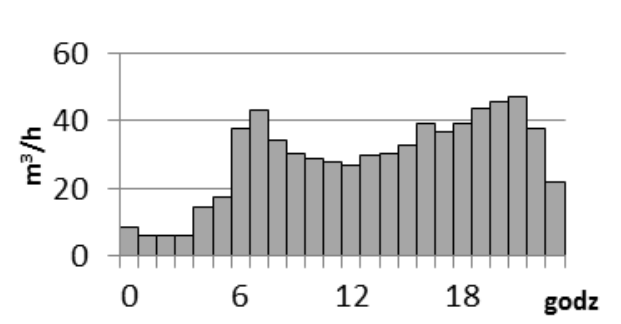

Rys. 3.d. Skorygowana konsumpcja wody

Fig. 3.d. Recalculated water consumption

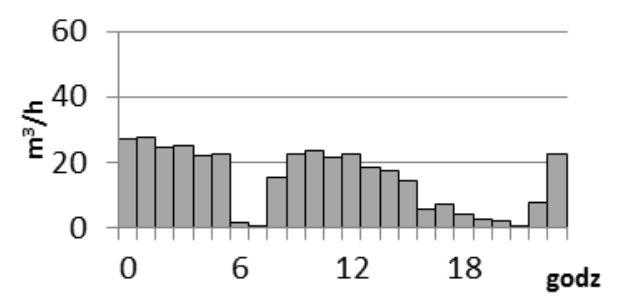

Rys. 3.e. Rozkład strat po korekcie konsumpcji - brak wartości ujemnych

Fig. 3.e. Chart of water loses after recalculation - lack of negative values 
Na rys. 3.a - 3.e przedstawiono kolejne kroki realizujące korektę wielkości sprzedaży wody i wielkości strat. Dysponując rozkładem na bazie pomiarów (rys. 3.a) oraz, przy założeniu rozkładu sprzedaży wody (rys. 3.b) wylicza się teoretyczny, przybliżony rozkład wody traconej (rys. 3.c). Gdy którakolwiek $\mathrm{z}$ wartości $\mathrm{w}$ tym rozkładzie jest ujemna, konieczna jest korekta założonego rozkładu sprzedaży wody poprzez jego proporcjonalne zmniejszenie i spłaszczenie (rys. 3.d), aż uzyskany rozkład wody traconej będzie pozbawiony wartości ujemnych (rys. 3.e). Ich suma w dalszym ciągu dokładnie odpowiada wartościom zmierzonym.

Finalnie, po wykonaniu opisanej procedury, model zapotrzebowania na wodę odwzorowuje ilość i zmienność w czasie charakterystyczną dla doby wykonania pomiarów. Poziom szczegółowości odwzorowania związany jest $\mathrm{w}$ dużej mierze $\mathrm{z}$ ilością punktów pomiarowych na sieci i wydzielonych w ten sposób stref bilansowania. Sam proces aktualizacji modelu zapotrzebowania na wodę, przy wcześniej zdefiniowanych relacjach między poszczególnymi pomiarami, sprowadza się do wskazania źródła danych o pomiarach i określenia daty, dla której zostanie odwzorowany stan systemu. Można powiedzieć, że odwzorowanie takie jest najbliższe rzeczywistym warunkom poboru wody w analizowanym systemie wodociągowym i stanowi podstawę do kalibracji hydraulicznej wskazanych obiektów wodociągowych, według przyjętych kryteriów dopasowania modelu do stanu rzeczywistego. Zagadnienie kalibracji obiektów wodociągowych również można w znacznym stopniu zautomatyzować, a procedurę taką opisano w kolejnym rozdziale.

\section{Autokalibracja pracy pomp}

Zagadnienie kalibracji pracy obiektów pompowych jest drugim tematem poruszanym w ramach niniejszego opracowania. Poprzez kalibrację pomp rozumie się tu odpowiednie dopasowanie w symulatorze nastaw obiektów tak, by w wynikach obliczeń uzyskać wartości ciśnienia tłoczenia lub wydajności jak najbliższe wielkościom zmierzonym. W przypadku modeli hydraulicznych o statycznie zdefiniowanym modelu zapotrzebowania na wodę, kalibracja wszystkich urządzeń wykonywana jest przez operatora jednorazowo, tak by dostosować ich parametry do wielkości oczekiwanych. Proces ten, pomimo że jest wykonywany jednorazowo jest zadaniem bardzo żmudnym i często zajmuje istotną część czasu przeznaczonego na stworzenie prawidłowo funkcjonującego modelu sieci. Należy tu zauważyć, że dla każdej pompowni występującej $\mathrm{w}$ systemie, należy prawidłowo zdefiniować parametry jej pracy w interwałach nie dłuższych niż godzinne, co przy dużej ilości obiektów pompowych może być bardzo czasochłonne. Alternatywą może być automatyzacja tego procesu, która pozwoli na precyzyjne odwzorowanie pracy obiektu przy minimalnej ingerencji ze strony operatora modelu. W powiązaniu z dynamiczną aktualizacją 
modelu zapotrzebowania na wodę, obie metody znacząco zwiększają użyteczność modelu i usprawniają jego eksploatację.

$\mathrm{W}$ aplikacji zaimplementowano autorski algorytm, który odwołując się do danych pomiarowych o pracy pompy, takich jak wysokość tłoczenia bądź wydajność, dokonuje modyfikacji parametru utożsamianego z mnożnikiem prędkości obrotowej wirnika pompy, tak by w każdym kroku czasowym nastawa obiektu w modelu skutkowała wynikiem pracy pompy, zbliżonym do wartości zmierzonej przy założonej dokładności dopasowania, przykładowo $\varepsilon \leq 0,1 \mathrm{~m}$.

W symulatorze, pompa odwzorowana jest jedynie poprzez charakterystykę zależności $h(Q)$, która może być modyfikowana poprzez zmianę wartości parametru $n$ będącego odpowiednikiem mnożnika fabrycznej prędkości obrotowej wirnika pompy. Zależności między tymi wielkościami przedstawione w równaniach (8) i (9) wg [2] pozwalają wyznaczyć nowy kształt charakterystyki pompy przy zmienionej prędkości obrotowej.

$$
\begin{aligned}
& \frac{Q_{1}}{Q_{2}}=\frac{n_{1}}{{ }^{2}} \\
& \frac{h_{1}}{h_{2}}=\left(\frac{n_{1}}{{ }_{n 2}}\right)^{2}
\end{aligned}
$$

gdzie:

$Q_{1}, Q_{2}$ - wydajności jednostki pompowej przy różnych prędkościach obrotowych,

$h_{1}, h_{2}$ - wysokość podnoszenia jednostki pompowej przy różnych prędkościach obrotowych,

$n_{1}, n_{2}$ - prędkości obrotowe wirnika pompy.

Prezentowany tu algorytm autokalibracji może służyć do dopasowania parametrów pracy pompy w zakresie ciśnienia bądź wydajności jednostki pompowej. Poszczególne kroki algorytmu w formie blokowej przedstawiono na rys. 4 na przykładzie kalibracji w zakresie ciśnienia tłoczenia dla jednego kroku czasowego i przy założonej dokładności dopasowania $\varepsilon$.

Algorytm przedstawiony na rys. 4. będzie funkcjonować prawidłowo w układzie wodociągowym z jedną pompownią. W przypadku obecności kilku pompowni konieczne jest rozważenie ich wzajemnych relacji hydraulicznych. Można tu rozróżnić obiekty, które tłoczą wodę do jednej strefy ciśnienia i je należy rozpatrywać równolegle, oraz obiekty, które pobierają wodę z takiej strefy i tłoczą do strefy kolejnej. Autokalibracja pompowni równoległych może odbywać się w jednym kroku iteracyjnym. Oznacza to, że wszystkie pompownie tego samego poziomu kalibrowane są w tym samym czasie. Parametry pracy pompowni pobierających wodę ze strefy niższego ciśnienia (w szczególności 


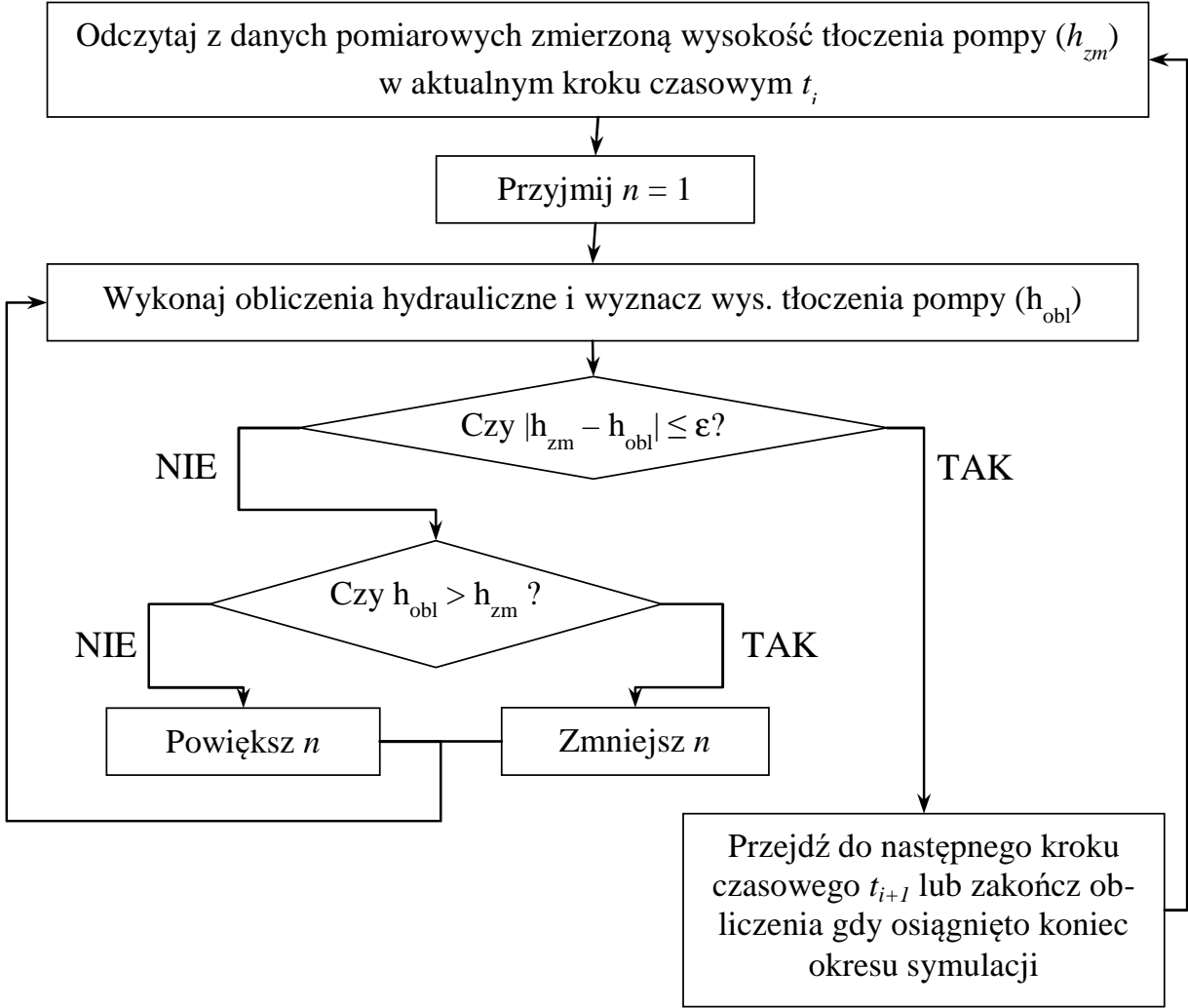

Rys. 4. Ramowy algorytm autokalibracji pompy

Fig. 4. Pump calibration algorithm

ciśnienie po stronie ssania) w dużej mierze zależą od pracy pompowni poprzedzających. $\mathrm{Z}$ tego względu należy je traktować jak połączone kaskadowo zaś sam proces autokalibracji winien być wykonany na nich w kolejnej iteracji, po uzyskaniu zbieżności wyników w pompowniach niższego rzędu. Oznacza to, że wcześniej prezentowany algorytm z rys. 4 winien być wykonywany wielokrotnie dla kolejnych pomp w układzie, w kolejności określonej przez operatora i zapisanej na liście hierarchiczności poszczególnych obiektów poddawanych kalibracji. Przykład zastosowania tego rozwiązania przedstawiono na rys. 5 oraz rys. 6, gdzie przedstawiono fragment systemu wodociągowego Nowego Sącza, oraz odpowiadającą mu listę hierarchiczności obiektów w procesie autokalibracji. Na pierwszych pozycjach tej listy znajdują się obiekty symulujące pracę ZUW, a na kolejnych - wybrane pompownie. Należy zauważyć, że pompownie nr 17, 22 i 28 są względem siebie równoległe i kalibrowane w tym samym kroku iteracyjnym. Pompownie nr 18 i 29 kalibrowane są po ustaleniu warunków pracy pompowni poprzedzających. 


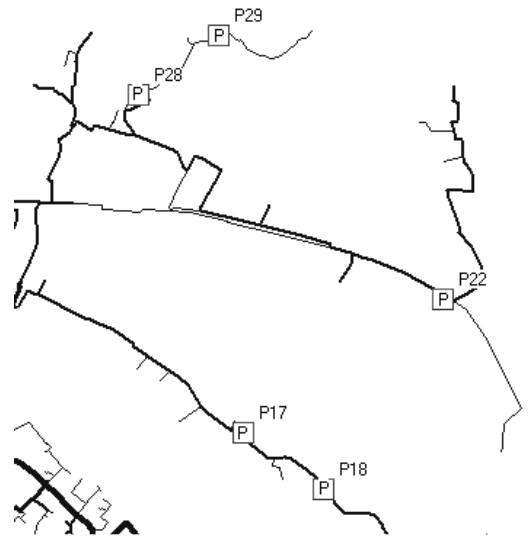

Rys. 5. Lokalizacja pompowni znajdujących się na liście hierarchiczności z rys 6

Fig. 5. Localization of pumps from hierarchical list mentioned in fig. 6

\begin{tabular}{|c|c|c|c|c|}
\hline Kolejność & Ob. kal. & Nazwa ob. kalibrowanego & Kalibrowana wielkość & Pomiar referencyiny \\
\hline Razem z poz. wyżej & $\operatorname{Rez}$ & R1: Świniarsko zasilanie m... & poziom zw. wody & 140 - Rzędna ciśn dla rez.1 do mag. PN ... \\
\hline Razem z poz. wyżej & $\operatorname{Rez}$ & R4: Swiniarsko zasilanie m... & poziom zw. wody & 141 - Rzędna ciśn dla rez.4 do mag. PD ... \\
\hline Razem z poz. wyżej & Rez & R3: Stary Sącz zasilanie m... & poziom zw. wody & 142 - Rzędna ciśn dla rez.3 do mag. SS-... \\
\hline W następnym kroku & Pom & P17: Długoszowskiego 1 & ciśn. tłoczenia & $66 \cdot \mathrm{H}$. Długoszowskiego $1 \cdot \mathrm{h}$ tłoczenia \\
\hline Razem z poz. wyżej & Pom & P28: Chruślicka 1 & ciśn. tłoczenia & 109 - H. Chruślicka 1 - $h$ troczenia \\
\hline Razem z poz. wyżej & Pom & P22: Lwowska & ciśn. tłoczenia & 74 - H. Lwowska 1 - h thoczenia \\
\hline W następnym kroku & Pom & P18: Długoszowskiego 2 & ciśn. tłoczenia & $68 \cdot \mathrm{H}$. Długoszowskiego $2 \cdot \mathrm{h}$ tłoczenia \\
\hline Razem z poz. wyżej & Pom & P29: Chruślicka 2 & ciśn. tłoczenia & $112 \cdot \mathrm{H}$. Chruślicka $2 \cdot \mathrm{h}$ troczenia \\
\hline
\end{tabular}

Rys. 6. Lista hierarchiczności obiektów poddawanych kalibracji

Fig. 6. Hierarchical list of calibrating objects

Na rys. 7 przedstawiono efekt działania algorytmu w formie wykresu z naniesionymi pomiarem ciśnienia tłoczenia (jaśniejsza linia) oraz ciśnieniem obliczonym w procesie autokalibracji (ciemniejsza linia). Rozbieżności między obydwoma wykresami nie przekraczają założonej dokładności $\varepsilon= \pm 0,1[\mathrm{~m}]$.

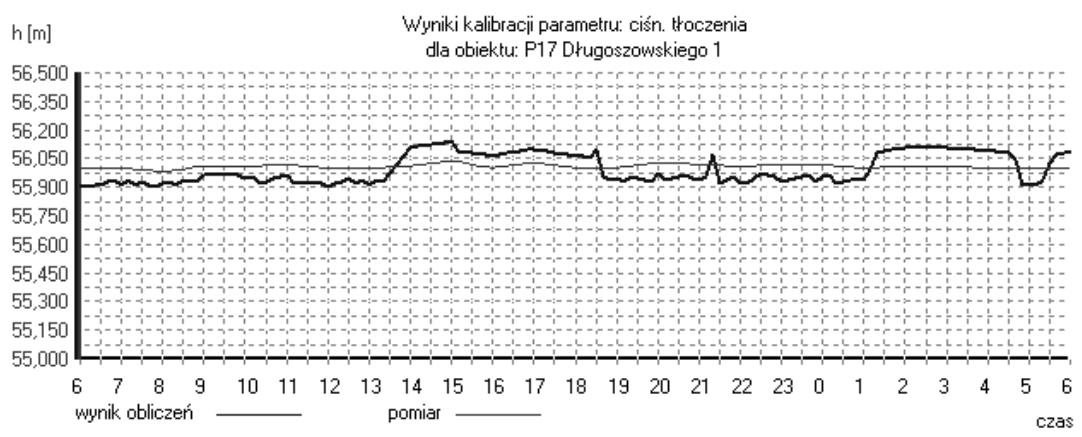

Rys. 7. Porównanie pomiaru i wyników obliczeń hydraulicznych ciśnienia tłoczenia w wybranej pompowni

Fig. 7. Comparison of measured and calculated pressure in pumping station 


\section{Wdrożenie}

Opisane rozwiązania zostały z powodzeniem zaimplementowane w kodzie autorskiego symulatora funkcjonowania systemów wodociągowych opierającego się na mechanizmach obliczeniowych zaczerpniętych z SDK Epanet 2. W symulatorze tym został stworzony szczegółowy model sieci wodociągowej eksploatowanej przez Sądeckie Wodociągi sp. z o.o. Wspomniany model wykorzystywany jest do bieżącej analizy funkcjonowania systemu, a dostęp do niego znajduje się na stanowisku dyspozytorskim. System wodociągowy Nowego Sącza podzielony jest na szereg stref bilansowania przepływów z wykorzystaniem przepływomierzy i ciśnieniomierzy umieszczonych w kluczowych lokalizacjach. Na bazie tego podziału, w modelu stworzono odpowiednie struktury pozwalające na odwzorowanie wielkości i zmienności zapotrzebowania oraz przepływu wody dla dowolnego dnia, dla którego dostępne są odczyty z przepływomierzy, w tym w szczególności dla dnia poprzedniego.

Bazując również na pomiarach wydajności i ciśnienia w pompowniach, oraz napełnienia zbiorników w dowolnie wybranym dniu, w modelu realizowany jest algorytm autokalibracji tych obiektów. Aktualnie, w celu aktualizacji modelu do dowolnie wybranego stanu spośród stanów historycznych, operator modelu musi jedynie w arkuszu kalkulacyjnym podać datę i wygenerować plik z wartościami pomiarów, a następnie taki plik zaimportować do symulatora. Pozostałe operacje związane $\mathrm{z}$ aktualizacją modelu zapotrzebowania na wodę oraz autokalibracji pompowni wykonują się w tle. Proces ten trwa w zależności od mocy obliczeniowej komputera od kilkunastu do kilkudziesięciu sekund.

\section{Podsumowanie}

Zaprezentowane rozwiązania poszerzają możliwości wykorzystania komputerowych modeli sieci wodociągowych oraz w znaczący sposób skracają czas ich aktualizacji w zakresie zmian parametrów eksploatacyjnych. Pomimo dużego potencjału użytkowego jakim są obdarzone, należy przyznać, że rozwiązania te nie są wolne od wad, w szczególności o charakterze numerycznym, prowadząc w niekorzystnych warunkach do niestabilności symulatora. Skuteczność ich stosowania w dużej mierze zależna jest od dostępności prawidłowych pomiarów terenowych. Na bieżąco prowadzone są prace nad udoskonalaniem prezentowanych metod obliczeniowych i zwiększeniem wiarygodności uzyskiwanych wyników. Według wiedzy autora, przedstawione rozwiązania są niedostępne w innych symulatorach, co czyni je unikatowymi, a wdrożenia $\mathrm{z}$ ich wykorzystaniem są działaniami pionierskimi.

$\mathrm{Na}$ aktualnym etapie rozwoju symulatora, możliwe jest odtworzenie warunków pracy w dowolnie wybranej pełnej dobie, przy dostępności danych pomiarowych. Planuje się rozwój oprogramowania w kierunku możliwości symulacji stanu bieżącego z opóźnieniem wynikającym jedynie z charakteru transmi- 
sji danych z punktów pomiarowych. Powinno to w jeszcze większym stopniu usprawnić eksploatację rozległych systemów wodociągowych, przy minimalnych nakładach pracy ze strony użytkownika.

\title{
Literatura
}

[1] Knapik K., Wierzbicki R., Płoskonka R.: Zastosowanie technik komputerowych $\mathrm{w}$ analizie funkcjonowania istniejących i projektowanych systemów zaopatrzenia w wodę, Materiały II Ogólnopolskiej Konferencji Naukowo - Technicznej, Szczyrk 5 - 6 czerwiec 2003, strony $131-139$.

[2] Rossman L. A.: Epanet 2 User's manual, U.S. Environmental Protection Agency, Cincinnati, OH 45268, EPA/600/R-00/057, September 2000.

[3] Rozporządzenie Ministra Infrastruktury z dnia 14 stycznia 2002 r. w sprawie określenia przeciętnych norm zużycia wody. Dziennik Ustaw, Nr 8, Poz. 70.

[4] Wytyczne do programowania zapotrzebowania wody i ilości ścieków w miejskich jednostkach osadniczych. Ministerstwo Administracji, Gospodarki Terenowej i Ochrony Środowiska, Warszawa 1978.

\section{AUTOMATION OF SELECTED UPDATE AND CALIBRATION PROCESSES IN WATER SUPPLY MODELS WITH VARYING CONDITIONS OF SERVICE}

\begin{abstract}
S u m m a r y
Water system modelling is becoming a more and more popular tool supporting management and utilization of modern waterworks companies. In the vast majority of cases, existing models represent a conventional level of utilization that corresponds to an average or maximum daily water demand. There are many technical and organizational obstacles preventing us from creation of a model which would map a current state of the water system. The study presents an original solution that extends the functionality of water system simulators and allows for significant automation of model calibrations in current conditions through updates and realignments of actual water demand, and adjustments of corresponding parameters of a pumping station. This solution has been presented in a form of a universal procedure that can be implemented in any water system simulator. It has already been used to extend the functionality of the native simulator based on Epanet software development kit and has been successfully tested and implemented in Nowy Sącz water system model.
\end{abstract}

Keywords: water supply model, water demand, Epanet, calibration

Przestano do redakcji: 30.08 .2015 r.

Przyjęto do druku: 1.03.2016 r.

DOI: $10.7862 /$ rb.2016.127 